\title{
Study of Verbal Bullying in Early Adolescents (Case Study of Pallangga 5 Junior High School and Sungguminasa 3 Junior High School)
}

\author{
Muh. Asrul Taufiq Arifuddin', Suriah², Sudirman Nasir ${ }^{2}$, \\ Muhammad Syafar ${ }^{2}$, Lalu Muhammad Saleh², Nurhaedar Jafar ${ }^{2}$ \\ ${ }^{1}$ Master Degree of Public Health Student, Faculty of Public Health, Hasanuddin University, \\ ${ }^{2}$ Lecturers of Faculty of Public Health, Hasanuddin University
}

\begin{abstract}
Bullying can take many forms, one of which is verbal bullying in the form of reproach, slander, cruel criticism, personal or racial insults. This study aims to examine the incidence of verbal bullying that occurs in early adolescents at Pallangga 5 Junior High School and Sungguminasa 3 Junior High School, Gowa Regency. This research uses a qualitative case study approach. Data was obtained through Focus Group Discussion (FGD), in-depth interviews with 59 informants and document review. Content analysis is used to identify topics or categories in the data. The results showed that the forms of verbal bullying varied, ranging from harassing, threatening, using verbal abuse by making fun of parents and the name of the victim. Therefore, schools should intensify the activities of the ambassador team so that verbal bullying can be minimized and teachers need to add insight into verbal bullying.
\end{abstract}

Keywords: Study, Verbal Bullying, Early Adolescence.

\section{Introduction}

Research on bullying began more than 40 years ago ${ }^{1}$. Bullying is aggressive behavior that is unwanted by other adolescents who are not siblings that involves a recurring imbalance of perceived power that causes physical, psychological, social or educational ${ }^{2,3}$, both between the victim and the perpetrator. Bullying is characterized by physical, social, or verbal abuse affecting large numbers of school children worldwide ${ }^{4}$. Bullying at school is an act of repeated aggression and is deliberately directed at students who have little position or power ${ }^{5}$. Therefore, learning in schools must be conducive, safe, and comfortable and away from actions that endanger students. The central government, local governments, and other state institutions are obliged

\section{Corresponding Author:}

Muh. Asrul Taufiq Arifuddin

Master Degree of Public Health Student, Faculty of Public Health, Hasanuddin University, e-mail:muhasrultaufiq097@gmail.com to guarantee a sense of security for themselves and the souls of students in their growth and development ${ }^{6}$.

The bullying that is rife in schools can be done by teachers to students, students to other students and a group of students to other students. UNICEF reports that in 2015 violence against children occurred widely in Indonesia, $50 \%$ of children were bullied at school. Meanwhile, WHO data for September 2016, 12\% of children in the world experienced sexual violence in the past year, even $37 \%$ of WHO member countries implemented interventions to prevent incidents of sexual violence on a larger scale. Meanwhile, the Indonesian Child Protection Commission (KPAI) released the results of monitoring cases of violations of children's rights in the education sector during 2019 which showed that acts of bullying or bullying of children against teachers increased drastically. From January to April 2019, bullying was dominated by bullying in the form of physical violence, psychological violence, and sexual violence. In addition, KPAI recorded 12 cases of psychological violence and bullying and 4 cases of children bullying their teachers. The majority of cases 
occurred at the primary school level, reaching 25 cases or $67 \%$ of the total cases. ${ }^{8}$.

Bullying can take many forms, including physical, verbal and mental. Bullying [9] ranges from verbal assaults (eg name calls, threats), physical behavior (eg hitting, kicking, damaging the victim's property), and social aggression (eg social exclusion, spreading rumors) to the latest forms of attack via the Internet and new technology (cyber bullying). This bullying behavior often occurs in school environments such as toilets, canteens and parks. In the context of this research, the researcher discusses verbal bullying. This type of bullying is very easy to find and occurs everywhere, such as acts of cursing, ridiculing, gossiping, making fun of and dwarfing, whether in the context of being intentional or not, joking or serious. This type of bullying can occur both in the family environment, in association, and even worse in the educational environment.

Observations on February 6, 2020 show that researchers obtained information from two State Junior High Schools in Gowa Regency who often engage in verbal bullying. From 2017 to 2019, in the case study at Pallangga 5 Junior High School there was verbal bullying of 4-5 people per class for at least one week. The trigger is a trivial thing, for example a student's pen is picked up by a classmate who is so angry that they keep laughing at each other's names. Meanwhile, at Sungguminasa 3 Junior High School, there are about 30 victims of bullying every year. Ironically, the perpetrators and victims come from people who are weak, easy to control and don't want to fight back. On January 27, 2020, an interview with a psychologist and consultant at the Integrated Service for Women's Empowerment and Child Protection, South Sulawesi Province obtained information on whether the training materials were designed with UNICEF support.

As a result, to form student facilitators, use the u-report platform to evaluate the school situation in cyberspace based on social media to conduct anonymous polls. In this way, at Pallangga 5 Junior High School and Sungguminasa 3 Junior High School, 74\% of students were found to be bullied, an average of 4 to 5 times a week. Types of bullying include being hit, blackmailed, teased, chatting, and being bullied online. The learning facilitator works with students to change negative behavior into positive behavior, helping students develop their own exercise based on problems at school. Activities that can be carried out include making posters, editing work plans for tackling bullying in schools, and modeling positive behavior.

The form of verbal bullying that occurs is adjusted to the conditions of the language and the habits of the local community, for example calling the names of their parents in a mocking tone to saying obscene words and hinting at their friends, for example sundala children (illegitimate children), ka'bulamma, asu '(dogs). The words are considered normal and come spontaneously from the mouth of the bully. Verbal bullying includes humor and ridicule, name calling, shouting, verbal rejection, negative predictions, negative comparisons, humiliation, cursing and swearing, and threats to children. Verbal bullying uses endless cursing and ridicule the victim, usually judged by his physical inadequacy, as well as denouncing his stupidity and hobbies, ethnicity, religion, and overall physique. ${ }^{11}$

Although verbal bullying does not cause physical harm, it does have a negative impact on the victim's psychological side and poor social adjustment. Psychologically, for example, excessive anxiety, constant fear, depression, suicidal thoughts and symptoms of post traumatic stress disorder. Meanwhile, the victim also had difficulties in adapting to the social environment, for example wanting to move to another school or leaving that school, having disrupted academic performance or often deliberately not attending school. Another characteristic of victims of verbal bullying is a relatively low level of self-confidence which is caused by continuous insults, threats and inappropriate words to the victim or the perpetrator does not want to acknowledge the victim's physical and non-physical strengths, causing fear, loss of self-confidence and the ability to act. In addition, embedding with ugly titles, fat, dwarf the victim by gossiping or vilifying. Another impact is that children's development is socially and emotionally stunted where children can grow up with low self-esteem and low self-concept.

When they grow up, they are more likely to continue to be victims of verbal bullying, or to turn into verbal bullies. They also have a higher tendency to behave aggressively and to engage in delinquency and selfdestructive behavior, such as drug use, alcohol abuse to attempted suicide. Victims of verbal bullying can also grow up to become personal with various kinds of psychological disorders, such as anxiety disorders, depression and emotional instability. 
It often happens that students who are victims of bullying tend to be shunned and isolated so that victims of bullying tend to carry out negative coping strategies such as truancy, violating school regulations, and being individual, and falling into promiscuity as a form of escape to problems that the victim of bullying cannot yet solve. In addition, the public's misperception of bullying which is considered normal will unconsciously cause negative views on children who are victims, including being gloomy, lazy to study, skipping school more often, and being ignored and ostracized by the surrounding environment.

This is of course a serious concern from various parties, but on the other hand, teachers or parents tend to understand or add negative labels or attributes to the victims of bullying. Therefore, the school has made efforts and actions so that verbal bullying does not happen again in the form of advice and lectures both on Friday worship, during flag ceremonies, every lesson hour is empty and every time learning starts even makes posters containing verbal bullying stops.

Based on the empirical facts above, the problem of verbal bullying is interesting to study in the context of research. Remembering verbal bullying will have a negative impact on early adolescence. Early adolescents according to Erickson ${ }^{12}$ are adolescents whose age criteria are 13-15 years old in girls and 15-17 years old in boys. According to WHO ${ }^{13}$, the age limit for adolescents is 12 to 24 years. ${ }^{14}$ Adolescents in these early days are still amazed at the changes that take place in their own bodies and the impulses that accompany them. They develop new thoughts, are quickly attracted to the opposite sex, and are easily sexually aroused. Excessive sensitivity coupled with reduced control (self-control) over the ego makes early adolescence difficult for adults to understand. This is in line with the theory of Low Self-Control ${ }^{15}$ which assumes that one of the causes of criminal behavior is low self-control and even associates the phenomenon of bullying with social criminal behavior and considers it a serious problem in relation to student safety in schools and threats to academic achievement. In addition, students who are raised in a family environment and authoritarian parents can also cause children to behave deviantly.

Based on the description above, education today can run well without any form of violence, so that a peaceful atmosphere is created and learning can take place well. Therefore, the authors would like to carry out a study entitled "Study of Verbal Bullying in Early Adolescents (Case Studies at SMP Negeri 1 Pallangga and SMP Negeri 3 Sungguminasa." This study aims to examine the incidence of verbal bullying that occurs in early adolescents in SMP Negeri 5 Pallangga and SMP Negeri 3 Sungguminasa, Gowa Regency.

\section{Materials and Method}

This research design uses a case study approach to understand the problem of verbal bullying in depth and identify cases of verbal bullying that are rich in information. The research was conducted at Pallangga 5 Junior High School and Sungguminasa 3 Junior High School, Gowa Regency, South Sulawesi Province. Research informants were selected by purposive sampling based on predetermined criteria with complete elaboration in order to obtain maximum results. The data collection technique used secondary data from the Integrated Service for Women Empowerment and Child Protection, South Sulawesi Province, while the primary data was obtained from observations, Focus Group Discussions (FGD), in-depth interviews, and document review. Data analysis uses content analysis or content analysis which is interpreted and presented in the form of a narrative, matrix and schema.

\section{Results and Discussion}

The researcher will descriptively describe the form of verbal bullying by quoting the results of in-depth interviews and FGDs from a number of informants who have been determined. Various opinions of informants regarding the forms of verbal bullying that occurred at Pallangga 5 Junior High School and Sungguminasa 3 Junior High School,GowaRegency . Forms of verbal bullying that have occurred in both schools are ridicule, seniority behavior between seniors and juniors, thuggery, and bullying that students often face. Something that is more serious is done by students who are bullies in the form of threats to their friends when they are not given, which results in humiliation of the physical form of the body.

Forms of verbal bullying can be ridicule, physical actions taken by students. Say, there are seniors and juniors where seniors are salt, big and so on. It can put pressure on the juniors. Actions like this are often done by others when interacting. Also thuggery because of the presence of seniors and juniors in it, there can be bullying that students often face. Both students from within the school and alumni who have finished and still 
have interaction with the school. Say they are already in high school but they still want to create old habits by blocking them outside the school environment such as doing bullying and so on.

(JA, 58 Years, 25 June 2020, 09.00 AM)

Triggered by trivial things such as being dwarfed/ mocked by calling the victim as his parent, being insulted because of his dwarf physical form, and so on. The forms of cases of verbal bullying that have occurred are mocking his friend, insulting his friend's physical form, threatening if the perpetrator asks for pocket money from his friend and is not given him.

(FM, 50 Years, 17 June 2020, 10.00 AM)

It was revealed that the form of verbal bullying that was carried out by students was in the form of taunts, physical actions that were part of the seniority system that still prevailed at school and continued to build communication with students who were inside the school by creating old habits from school time by blocking them outside the school environment such as bullying. and so on so that it leads to threats and humiliation of the physical form of their friends that students often face. In the FGD, the student perpetrator said that he often made fun of and changed his friend's name to the name of his parents, gave bad words and even insulted, ordered him to and fro and hid his friends' belongings. The counseling teacher and homeroom teacher revealed that mocking and insulting the physical form of friends, calling parents' names, bullying and threatening friends when their wishes were not fulfilled, which was often done by the perpetrator, was revealed in the results of the interview below:

Forms of verbal bullying that have occurred include mocking his friend, insulting his friend's physical form, threatening if the perpetrator asks for pocket money from his friend when he is not given him.

(HA, 41 Years, 26 June 2020, 10.00 AM)

For example, at school, students call their friends not their names but the names of their parents. For example, his name Aswan is called Dg. Beta because his parents are named Dg. Beta or physically he was ordered to go shopping. So, children are forced to do not because of desire but because of fear. Or something is being interrogated by a friend.

(TA, 44 Years, 17 June 2020, 13.00 PM)

Harass or threaten his friend to submit with harsh verbal such as "puppy or" sundala "(illegitimate child)”. (MI, 36 years old, 27 June 2020, 10.30 AM)

Yes, that was mocking his friend with words about his physical condition like if he is black, he is called black, if he is "frizzy" maybe he is called "frizzy", maybe so. (HL, 57 Years, 18 June 2020, 10.00 AM)

There are those who say, there are those who behave or act that makes other people uncomfortable with the behavior they do.

(SP, 50 years old, 18 June 2020, 12.00 PM)

The interview excerpt above, shows that the form of verbal bullying that occurs at school is mocking, insulting the physical form of the body, threatening friends if they are not given what they want, harassing or threatening friends to submit by using harsh words such as puppies or harasses haram), calling parents' names, nicknames that are made fun of, mentioning inappropriate words. Meanwhile, students who were victims of verbal bullying said that their parents' names were made fun of and called the victims not their names. In the FGD, the perpetrator student admitted that he often made fun of his friend by calling him not a friend, not his real name, calling the names of parents to the names of animals. Thus, it can be concluded that the form of verbal bullying that occurs refers to the act of expressing certain words or verbal words from the offender to offend his friend as a victim of verbal bullying.

This was also conveyed by the parents of the perpetrator students in the FGD who admitted that their children often made fun of, mocked, ridiculed, alienated their friends, and used verbal abuse between their children and victims. For parents of victim students based on the results of in-depth interviews with researchers about the form of verbal bullying experienced by their children, they are described separately and briefly as follows:

The forms of verbal bullying that children have experienced are being said by their friends instead of their names and making fun of their peers.

(HS, 33 Years, 20 July 2020, 14.00 PM)

Forms of verbal bullying that have been experienced by children are the behavior of mocking children at school and outside of school.

(KE, 38 Years, 29 July 2020, 14.00 PM)

According to the parents of the victim, the form of verbal bullying that has been experienced by the child is the behavior of being ridiculed by friends at school and 
outside of school until the child gets ridicule treatment and even the child is called not his real name. In the FGD, the parents of the victims of the students expressed the same thing if their children often got ridiculed by calling them not their names, sometimes with the names of their parents which resulted in ridicule.

Based on the results of the interviews and the results of the FGD, it was found that the forms of verbal bullying that were carried out by the students varied, from making fun of, threatening and insulting the physical form of friends to the form of bullying that was often faced by victim students when the perpetrator's wishes were not fulfilled. This is due to the existence of peers who are one of the factors that influence verbal bullying at school. Peers are one of the biggest factors in someone engaging in verbal bullying. When a child has entered adolescence, he is no longer dependent on family, but tries to find support from his peers [16]. About $20-25 \%$ of teenagers are directly involved in bullying as perpetrators, victims, or both. Large-scale studies conducted in Western countries show $4-9 \%$ of adolescents frequently engage in bullying and $9-25 \%$ of school-age children in bullying.

The cause of verbal bullying in the form of direct contact is because it often annoys others by deliberately making fun of parents' nicknames and talking dirty to others. This finding is in line with the results of the study that direct verbal contact is part of the talk of violence directly to someone. For example spreading gossip, criticizing or teasing, cursing, giving nicknames, and so on ${ }^{17}$. Forms of verbal bullying behavior shown by the perpetrator to the victim can be in the form of mocking, insulting, and offensive remarks ${ }^{18}$. Storey has the view that verbal bullying includes mocking, yelling, making fun of and insulting ${ }^{19}$. Verbal bullying is a form of bullying behavior that can be captured through auditory envy. Forms of verbal bullying include: calling, yelling, scolding, insulting, humiliating in public, accusing, shouting, spreading gossip, and slandering .

Bullying behavior in schools is a pattern of negative behavior that is repeated and aims negatively. This behavior leads directly from one child to another because of an imbalance in power that aims to bully the weaker child. Bullying behavior in schools with the form of direct verbal contact, namely behavior that is in the form of talking directly to someone, forms of behavior that often occur such as talking dirty and mocking by carrying the name of the parents $\mathrm{s}^{20-28}$.

\section{Conclusions and Suggestions}

The results of the study concluded that the forms of verbal bullying that occurred varied, ranging from harassing, threatening friends, using harsh words, calling parents' names and nicknames which were made fun of. Therefore, schools should intensify the activities of the ambassador team so that verbal bullying can be minimized and teachers need to add insight into verbal bullying.

Ethical Clearance: Obtained from Faculty of Public Health Ethical committee.

\section{Source of Funding: Self}

\section{Conflict of Interest: None}

\section{References}

1. Menesini, E. \& Salmivalli, C., bullying in schools: the state of knowledge and effective interventions. Psychology, Health \& Medicine, 22:sup1, 240-253. https://doi.org/10.1080/13548506.2017.1279740. [Diakses 15 Maret 2020], 2017.

2. Carretero, C. M. danCervello, E., 2019. Teaching styles in physical education: a new approach to predicting resilience and bullying. International Journal of Environmental Research and Public Health. 2019; Spain: Department of Sport Sciences, Sport Research Center, Miguel Hernández University.

3. Mucheraha, W, Fincha, H, Whitea, T, \& Thomas, $\mathrm{K}$, The relationship of school climate, teacher defending and friendson students' perceptions of bullying in high school. Journal of Adolescence. Elsevier Ltd: Department of Educational Psychology, Ball State University, Muncie, 2018. IN 47306, USA.

4. Cho, S. \& Lee, J. M. Explaining physical, verbal, and social bullying among bullies, victims of bullying, and bully-victims: Assessing the integrated approach between social control and lifestyles-routine activities theories [Online]. Children and Youth Services Review; 2018.; doi:10.1016/j.childyouth. 2018.06.018. [Diakses 24 Februari 2020].

5. Skubic, D. Verbal abuse in kindergarten and primary school. Ars \& Humanitas, 2018; 12(1), 104-123. https://doi.org/10.4312/ars.12.1.104-123 
6. Info Datin. Kekerasanterhadapanakdanremaja. Jakarta: Pusat Data danInformasi Kementerian Kesehatan Republik Indonesia. 2018.

7. Maradewa, R., Catatan KPAI di Hardiknas: kasusanakbully guru meningkatdrastis. [online]. https://www.kpai.go.id/berita/catatan-kpai-dihardiknas-kasus-anak-bully-guru-meningkatdrastis. [Diakses 15 Maret 2020].2019.

8 Maradewa, R., Catatan KPAI di Hardiknas: kasusanakbully guru meningkatdrastis. [online]. https://www.kpai.go.id/berita/catatan-kpai-dihardiknas-kasus-anak-bully-guru-meningkatdrastis. [Diakses 15 Maret 2020].2019.

9. Monks, F.J., Knoers, A.M. P. \& Haditono, S.R. Psikologi Perkembangan Pengantardalamberbagaibagiannya. Yogyakarta: Gadjah Mada University Press. 2006.

10. Marks, D. F. The health psychology reader. London: Sage. 2002

11. Suciartini, N. N. A. dan Sumartini, N. P. U., Verbal bullyingdalam media sosial. Jurnal Pendidikan Bahasa Indonesia. PBSI 2018.; Vol.6 No.2, JuliDesember 2018. Sekolah Tinggi Manajemendan Ilmu Komputer (STMIK) STIKOM Bali.

12. Thalib, S.B. Psikologipendidikanberbasisanalisisempirisaplikatif. Jakarta: Kencana Media Group..2010.

13. Widyastuti, Y., et., al. Kesehatanreproduksi. Yogyakarta: Fitrimaya. 2009

14. Sarwono, S. Psikologiremaja. Jakarta: PT. Raja Grafindo. 2011.

15. Moon, B., Hwang, H.W., \& McLuskey, J. D. Causes of school bullying: Empirical test of a general theory of crime, differential association theory, and general strain theory. Crime \& Delinquencyi, 2008.; 57(6), 849877. Diunduhdarihttp://journals.sagepub.com/ doi/pdf/10.1177/00111287 08315740.

16. Goodwin, D., Strategies to deal with bullying. North Richmond, NSW: Kidsreach Inc. 2009.

17. Wiyani, N. A., Save our children from school bullying. Yogyakarta: Ar-Ruzz Media.2013.

18. Dewi, Putu Yulia Angga. Perilakuschool bullying padasiswasekolahdasar. Edukas I: Jurnal Pendidikan Dasar ISSN 2721-3935., 2020; Vol. 1, No. 1, Maret 2020, pp. 39-48. Sekolah Tinggi Agama Hindu Negeri MPU KuturanSingaraja, Indonesia.
19. Hertinjung, W.S. Bentuk-bentukperilaku bullying di sekolahdasarmenggunakanskalabentukbullying. Jurnal Prosiding Seminar Nasional Parenting Vol 2013.; (3): 450-458

20. Putri, H., Nauli, F., Novayelinda, R. Faktorfaktor yang berhubungandenganperilaku bullying padaremaja. JOM ., 2015.; Vol 2 No 2. Program Studi Ilmu Keperawatan Universitas Riau.

21. Masni, Saifuddin Sirajuddin, Syaharuddin and AminuddinSyam., Influence of a red palm oil emulsion on the level of retinol in the plasma of primary school childre., Pakistan Journal of Nutrition | vol: 15., issue: 5. 2016-01-01

22. RosmalaNur and Anwar Mallongi, Impact of Violence on Health Reproduction Among Wives in Donggala. Pakistan Journal of Nutrition, 2016.; 15: 980-988. DOI:10.3923/pjn.2016.980.988

23. Muhammad Awal, Ridwan Amiruddin, Sukri Palutturi and Anwar Mallongi, Relationships Between Lifestyle Models with Stroke Occurrence in South Sulawesi, Indonesia. Asian Journal of Epidemiology, 2017;10: 83-88

24. Mallongi, A., Daud, A., Ishak, H., La Ane, R., Birawida, A.B., Ibrahim, E., Selomo, M., Rahman, S.A. Clean water treatment technology with an upflow slow sand filtration system from a well water source in the tallo district of Makassar. Journal of Environmental Science and Technology, 2017; Volume 10, Issue 1, Pages 44-48

25. Masriadi, Azis, R., Sumantri, E., Mallongi, A., Effectiveness of non pharmacologic therapy through surveillance approach to blood pressure degradation in primary hypertension patients, Indonesia., Indian Journal of Public Health Research and Development. Volume 9, Issue 4, April 2018, Pages 249-255

26. Palutturi, S., Rutherford, S., Davey, P., Chu, C., Professional challenges to strengthen partnerships in the implementation of healthy cities in Indonesia: A case study of Makassar, Research Journal of Medical Sciences., Volume 8, Issue 4, 17 August 2014, Pages 126-132.

27. Mallongi, A., Stang, Syamsuar, Natsir, M.F., Astuti, R.D.P., Rauf, A.U., Rachmat, M., Muhith, A., Potential ecological risks of mercury contamination along communities area in tonasa cement industry Pangkep, Indonesia. Enfermeriaclinica, Volume 30, 1 June 2020, Pages 119-122 
28. Muhith A, Winarti E, Perdana SSI, Haryuni S, Rahayu KIN, Mallongi A. Internal Locus of Control as a Driving Factor of Early Detaction Behavior of Servical Cancer by Inspection Visual of Acetic Acid Method. Open Access Maced J Med Sci. 2020Apr 20; 8(E):113-116. https://doi. org/10.3889/oamjms.2020.43 